\section{Grant scheme put in doubt}

\section{London}

THERE is growing consternation at the prospect that the European Commission's only programme of support for science projects will virtually cease to exist later this year.

The grant-making scheme known as the SCIENCE programme, which offers competitive grants for basic research projects involving people and laboratories in more than one member state, may well lapse after the next grant-making round in September. To be eligible for grants at that meeting, proposals are due in Brussels in June this year.

The SCIENCE programme appears to have been the victim of the ambitious scheme to spend the bulk of the commission's science money on a programme of bursaries for European postgraduate students, put forward 18 months ago by Filippo Pandolfi, the research commissioner who is also vicepresident of the commission.

In its original form, dating from April 1990, the Pandolfi proposal, entitled "human capital and mobility", would have spent the bulk of 518 million European Currency Units (ECU; about $£ 370$ million) over four years on postgraduate bursaries tenable at universities and other research institutes outside the holders' own countries.

The plan has engendered controversy both within the commission and outside. While spending on fellowships is generally applauded, the justification of the scale of the proposed expansion, which would have financed 5,000 person-years of work away from the holders' institutions, was not self-evident.

A further objection was that intending holders of commission bursaries would not compete for them directly, but that awards would be made by "centres of excellence" in member states, which have yet to be selected. There are many who fear that the selection process, necessarily invidious, would entail political rather than intellectual judgement.

Several attempts to modify the scheme have been made, notably towards the end of last year by CREST, the commission's high-level advisory committee on which governments are represented by their own scientific advisers. Alan Howarth, UnderSecretary of State for Education and Science, told the House of Commons on 18 December that CREST was working on a proposal to continue present activities, the SCIENCE programme included, while increasing support for fellowships. But a commission spokesman says that CREST's compromise has "not been accepted".

More recently, a committee of the European Parliament has put forward a morning of 22 February. second compromise which observers believe is more likely to be acceptable to Pandolfi and the commission. Among other things, the San Fernandez report emphasizes the importance of encouraging 'twinning' relationships between pairs of European laboratories, which is one of the end-results of the SCIENCE programme. of Ministers, the periodic meetings of research ministers. One commission official thinks it unlikely that there will be agreement on how to spend the outstanding 518 million ECU this year.

Meanwhile, Sir Peter SwinnertonDyer, chairman for the past four years of the committee called CODEST that administers the SCIENCE programme, says he is "dismayed" at the events that threaten to bring the SCIENCE programme to an end. Sir Peter is retiring from CODEST, at the end of his four-year stint, after its March meeting. No successor has been appointed.

This development is all the more puzzling because that programme, which costs an average of 35 million ECU a year, has recently been given what another commission spokesman calls "one of the most glowing" of evaluations, by an independent panel chaired by Sir Sam Edwards, director of the Cavendish Laboratory at Cambridge. John Maddox
But the final say rests with the Council

\section{SPUR to innovation}

\section{London}

THE UK Department of Trade and Industry (DTI) has launched a new three-year £32-million scheme to encourage research and development (R\&D) in small British companies. Support for Products Under Research (SPUR) will provide 30 per cent of the cost of specific R\&D projects, up to a maximum of $£ 150,000$, for companies with fewer than 500 employees, and will focus on the development of commercial products - so-called 'near market' research.

Over the past few years, the government has reduced its funding for near-market research, arguing that this should be supported by the private sector.

DTI, for example, reduced its spending on industrial innovation from almost $£ 120$ million to just over $£ 70$ million in real terms between 1987-88 and 1989-90. But John Mulvey, from the Save British Science pressure group, says that private companies have been slow to close the gap left by government: "You cannot rely on the market to lead to investment in R\&D."

Launching SPUR last week, Trade and Industry Secretary Peter Lilley conceded that "there is a case for catalysing and improving" the R\&D efforts made by private companies. Mulvey welcomes the new scheme, but questions whether it is large enough to have a significant effect.

PeterAldhous

\section{Einstein brought down to size}
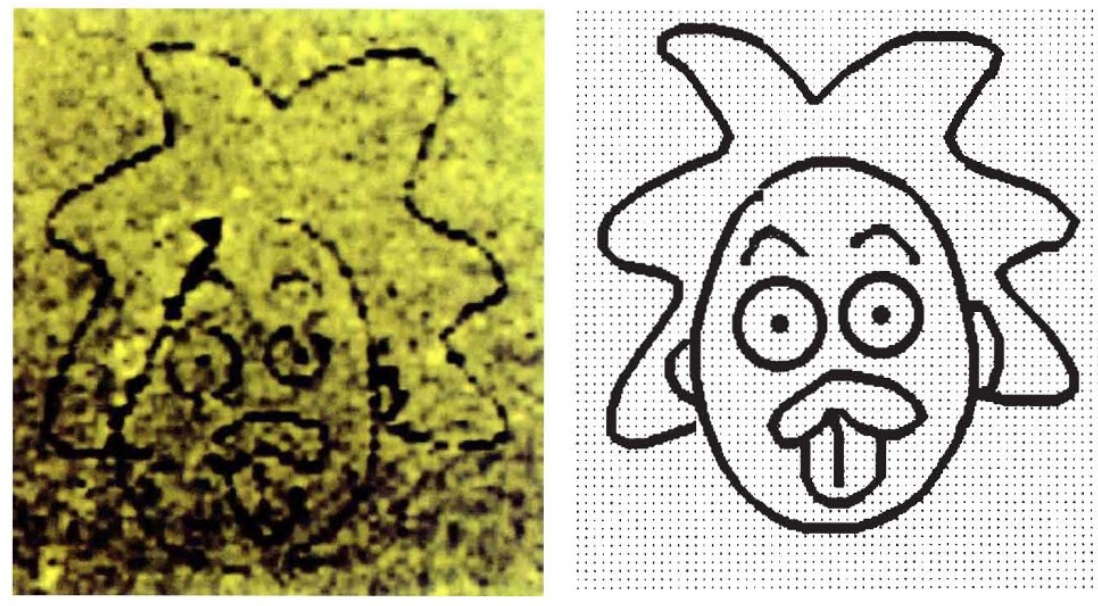

WHEN Einstein stuck his tongue out in a famous pose many years ago he probably did not expect that one day his action would be reproduced at the nanometre level. But that is what a Japanese researcher at Nippon Telegraph and Telephone Corporation has done using a nanometre-scale chemical etching process.

Yasushi Utsugi of the Corporation was asked to produce the rianometre-sized rendition of the eminent scientist by Fuji TV broadcasting company after Utsugi published a paper in Nature on his chemical etching technique (Nature 347,$747 ; 1990$ ). The picture will be broadcast on Fuji TV's late-night popular science programme Einstein next week early in the

Utsugi used a scanning tunnelling microscope controlled by a computer program to etch out the picture on the surface of a mixed-ionic conductor.

David Swinbanks, Tokyo 